\title{
Personality traits, work experience and GPA as predictors of Career Adaptability in College Students
}

\author{
ANNA VERES ${ }^{1}$
}

ISTVÁN SZAMOSKÖZI ${ }^{2}$

\begin{abstract}
Career adaptability is becoming a more and more important psychosocial construct in career counseling. It refers to the capability to adapt and mange career tasks and challenges. The main goal of the current paper was to investigate the effects of socio-demographic characteristics, work experience, GPA and HEXACO-60 on career adaptability, and its subscales (concerns, control, curiosity, confidence). Data was collected from 328 college students, from the Babeş-Bolyai University, Cluj-Napoca. The main aim of the study was to investigate whether the HEXACO-60 is as useful as the Big5. The six dimensions test is also a good predictor of career adaptability, except for the Emotionality dimension. In this sample, work experience was not a predictor for career adaptability, even if they were correlated. Career adaptability only in Step 2 was predicted by GPA, while in step 3 by father's educational level. Our findings support that HEXACO-60 personality inventory is useful for understanding and revealing the predictors of career adaptability.
\end{abstract}

\section{Keywords}

career adaptability, personality, HEXACO, GPA, work experience

1. Corresponding author: Anna Veres, e-mail: anna.veres@ubbcluj.ro, PhD student, BabeșBolyai University, Evidence-based Assessment and Psychological Interventions Doctoral School, Cluj-Napoca, Romania

2. Prof. Dr. István Szamosközi, Babeș-Bolyai University, Faculty of Psychology and Educational Sciences, Department of Applied Psychology, Cluj-Napoca, Romania 


\section{References}

Ashton, M. C., \& Lee, K. (2007). Empirical, theoretical, and practical advantages of the HEXACO model of personality structure. Personality and Social Psychology Review, 11(2), 150-166. doi: 10.1177/1088868306294907.

Ashton, M. C., \& Lee, K. (2009). The HEXACO-60: A short measure of the major dimensions of personality. Journal of Personality Assessment, 91(4), 340-345. doi: 10.1080/00223890902935878

Ashton, M. C., Lee, K., \& de Vries, R. E. (2014). The HEXACO Honesty-Humility, Agreeableness, and Emotionality Factors: A review of research and theory. Personality and Social Psychology Review, 18, 139-152. DOI: $10.1177 / 1088868314523838$

Biemanna, T., Zacherb, H. and Feldmanc, D.C. (2012), “Career patterns: a twentyyear panel study”. Journal of Vocational Behavior, 81(2), 159-170, doi: 10.1016/j.jvb.2012.06.003.

Hirschi. A. (2009). Career Adantabilitv Develobment in Adolescence: Multible Predictors and Effect on Sense of Power and Life Satisfaction. Iournal of Vocational Behavior, 74(2), 145-155 DOI: 10.1016/j.jvb.2009.01.002

Li, Y., Guan, Y., Wang, F., Zhou, X., Guo, K., Jiang, P., Mo, Z., Li, Y., \& Fang, Z. (2015). Big-five personality and BIS/BAS traits as predictors of career exploration: The mediation role of career adaptability. Journal of Vocational Behavior, 89, 39-45. doi:10.1016/j.jvb.2015.04.006 Guan, Y., Dai, X., Gong, Q., Deng, Y., Hou, Y., Dong, Z., Wang, L., Huang, Z. \& Lai, X. (2017). Understanding the trait basis of career adaptability: A two-wave mediation analysis among Chinese university students. Journal of Vocational Behavior, 101, 32-42. http://dx.doi.org/10.1016/j.jvb.2017.04.004

McCrae, R. R. \& Costa, P. T. (1987). Validation of the Five-Factor Model of Personality across Instruments and Observers. Journal of Personality and Social Psychology, 52(1), 81-90. http://dx.doi.org/10.1037/0022-3514.52.1.81

Monteiro, S. \& Almeida, L.S. (2015) The relation of career adaptability to work experience, extracurricular activities, and work transition in Portuguese graduate students. Journal of Vocational Behavior, 91, 106-112. doi: 10.1016/j.jvb.2015.09.006 
Negru-Subtirica, O. \& Pop, E. I. (2016). Longitudinal links between career adaptability and academic achievement in adolescence. Journal of Vocational Behavior, 93, 163-170. http://dx.doi.org/10.1016/j.jvb.2016.02.006

Nilforooshan, P. \& Salimi, S. (2016). Career adaptability as a mediator between personality and career engagement. Journal of Vocational Behavior, 94, 1-10. http://dx.doi.org/10.1016/j.jvb.2016.02.010

Pouyaud, J., Vignoli, E., Dosnon, O. \& Lallemand, N. (2012). Career adapt-abilities scale-France form: Psychometric properties and relationship to anxiety and motivation. Journal of Vocational Behavior, 80, 692-597. http://dx.doi.org/10.1016/j.jvb.2012.01.021

Rossier, J., Zecca, G., Stauffer, S. D., Maggiori, C. \& Dauwalder, J. (2012). Career Adapt-Abilities Scale in a French-speaking Swiss Sample: Psychometric properties and relationship to personality and work engagement. Journal of Vocational Behavior, 80, 734-743. doi:10.1016/j.jvb.2012.01.004

Savickas, M. L. \& Portfeli, E. J. (2012). Career Adapt-Abilities Scale: Construction, reliability, and measurement equivalence across 13 countries. Journal of Vocational Behavior, 80, 661-673. doi:10.1016/j.jvb. 2012.01.011

Savickas, M.L. (1997), "Career adaptability: an integrative construct for life-span, life-space theory”. The Career Development Quarterly, 45, 247-259, doi:10.1002/j.21610045.1997.tb00469.x.

Sullivan, S.E. and Arthur, M.B. (2006), “The evolution of the boundaryless career concept: examining physical and psychological mobility". Journal of Vocational Behavior, Vol. 69, pp. 19-29, doi:10.1016/j.jvb.2005.09.001.

Szirmák, Zs. \& De Raad, B. (1994). Taxonomy and structure of Hungarian personality traits. European Journal of Personality, 8(2), 95-117. DOI: $10.1002 /$ per.2410080203

Teixeira, M. A. P., Bardagi, M.P., Lassance, M. C. P., Magalhaes, M. O. \& Duarte, M.E. (2012). Career Adapt-Abilities Scale-Brazilian Form: Psychometric properties and relationship to personality. Journal of Vocational Behavior, vol.: 80, 680-685. doi: 10.1016/j.jvb.2012.01.007

van Vianen, A. E.M., Klehe, U. Koen, J. \& Dries, N. (2012). Career adapt-abilities scale - Netherlands form: Psychometric properties and relationship to ability, personality, and regulatory focus. Journal of Vocational Behavior, 80, 716-724. https://doi.org/10.1016/j.jvb.2012.01.002 
Veres, A., Farcas, Zs, Petric, E. \& Szamosközi, I. (2017) Career Adapt-Abilities Scale-Transylvanian Hungarian Form: Psychometric Properties and Relationship to Work Experience, In Conference Proceedings, 4th International Multidisciplinary Scientific Conference on Social Sciences \& Arts SGEM, Section Psychology and Psychiatry, (pp. 51-58) Albena Co., Bulgaria: STEF92 Technology Ltd.

Zacher, H. (2014) Career adaptability predicts subjective career success above and beyond personality traits and sore self-evaluations. Journal of Vocational Behavior, 84, 21-30. DOI: 10.1016/j.jvb.2013.10.002

Zecca, G., Györkös, C., Becker, J., Massoudi, K., de Bruin, G.P., \& Rossier, J. (2015). Validation of the French Utrecht Work Engagement Scale and its relationship with personality traits and impulsivity. Revue Européenne de Psychologie Appliqué, 65, 19-28. http://dx.doi.org/10.1016/j.erap.2014.10.003. 